\title{
河ロ干潟の環境と水産生物資源の変動に関する 現地観測 一大分県番匠川河ロ干潟のアサリを対象として- FIELD SURVEY OF ENVIRONMENT AND CHANGE IN MARINE PRODUCTS ON THE BEHAVIOR OF THE CRAM POPULATION IN THE TIDAL FLAT OF THE BANJO RIVER IN OITA
}

\author{
高見 徹 1 - 東野 誠 $^{2} \cdot$ 井上徹教 3 - 中茂義晶 4 ・安達貴浩 5 ・清野聡子 6 \\ 別府五男 7 ・郡山貞次 7 - 小松利光 8 \\ Tohru TAKAMI, Makoto HIGASHINO, Tetsunori INOUE, Yoshiaki NAKASHIGE, Takahiro \\ ADACHI, Satoquo SEINO, Itsuo BEPPU, Sadaji KOORIYAMA and Toshimitsu KOMATSU \\ ${ }^{1}$ 正会員 博 (工） 大分工業高等専門学校助手 土木工学科（广870-0152 大分市大字牧1666） \\ 2 正会員 博 (工) 大分工業高等専門学校助教授 土木工学科（同上） \\ 3正会員 博（工）（独）空港港湾技術研究所 海洋・水工部（广239-0826 横須賀市長瀬3-1-1) \\ 4 学生会員 九州大学大学院 工学府海洋システム工学専攻（テ812-8581 福岡市東区箱崎6-10-1)

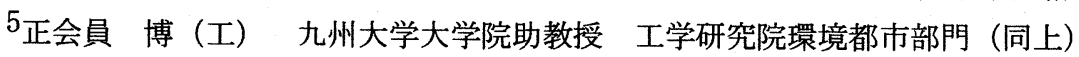 \\ 6 正会員 東京大学大学院助手 総合文化研究科（广153-8902 東京都目黒区駒場3-8-1） \\ 7 国土交通省九州地方整備局佐伯工事事務所（广876-0813 佐伯市長島町4-14-14） \\ 8 フェロー 工博 九州大学大学院教授 工学研究院環境都市部門（广812-8581 福岡市東区箱崎6-10-1）
}

\begin{abstract}
A field survey was performed in order to investigate the effect of water quality and characteristics of the sediment on change in marine products in the tidal flat of the Banjo River in Oita. The population of cram has decreased there recently. The sampling points were set in the tidal flat about $2.5 \mathrm{~km}$ upstream from the entry of Banjo River. The water quality, i.e. water temperature, $\mathrm{pH}, \mathrm{DO}, \mathrm{BOD}, \mathrm{COD}, \mathrm{SS}$, nitrogen and phosphorus, characteristics of the bottom sediment, i.e. grading and amount of heavy metals contained in the sediment, and population of marine products, i.e. density of cram, distribution of shell lengths of crams and density of algae have been examined in each month. The influence on the decrease in the population of cram is discussed based on the observed data.
\end{abstract}

Key Words : cram, fishery resource, Banjo River, tidalflat

\section{1. はじめに}

河川感潮域では潮汐周期に伴って水没, 干出を繰り 返す干潟が形成され，様々な有機物生産の場となって いる. また，河口干潟では，その環境条件に応じて生 態系が形成され，そこに生息する多様な魚貝類は水産 生物資源としての役割を果たしてきた. しかし，近年， 全国各地で自然的・人為的要因による水域生態系の劣 化が顕在化し，その結果，水産生物資源の減少等の問 題が深刻化している．これらの多くは，生息地の破壊 や水域水質の悪化等の複合的要因が複雑に絡夕合って
いるが，できるだけ原因を究明して何らかの対策を講 ずる必要がある. 河口干潟の生態系の問題には, 河口 域の水理・水質特性が深く関与する. したがって, 検 討に際しては生態学的視点のみならず，水理学・水質 工学的手法の導入が必要である. 近年, 大分県八坂川 河口沖干潟におけるカブトガニの生態と水理特性の関 係についての現地観測および数值シミュレーションに よる検討1)や，吉野川河口干潟におけるシオマネキの生 態と水理特性の関係についての検討和等が行われている. 本研究は，アサリの急激な減少が問題となっている大 分県番匠川の河口干潟を調查対象水域として，上述の 複合的要因が生態系および水産生物資源の劣化に及ぼ 
す影響について検討するものである．しかし，これら に関する過去の調査はほとんど行われていない，した がって，本論文ではまずアサリの急减の原因を究明す るため, アサリの生態と水理・水質諸量ならびに底質 との関係について現地観測による検討を行った.

\section{2. 調查対象水域の概要}

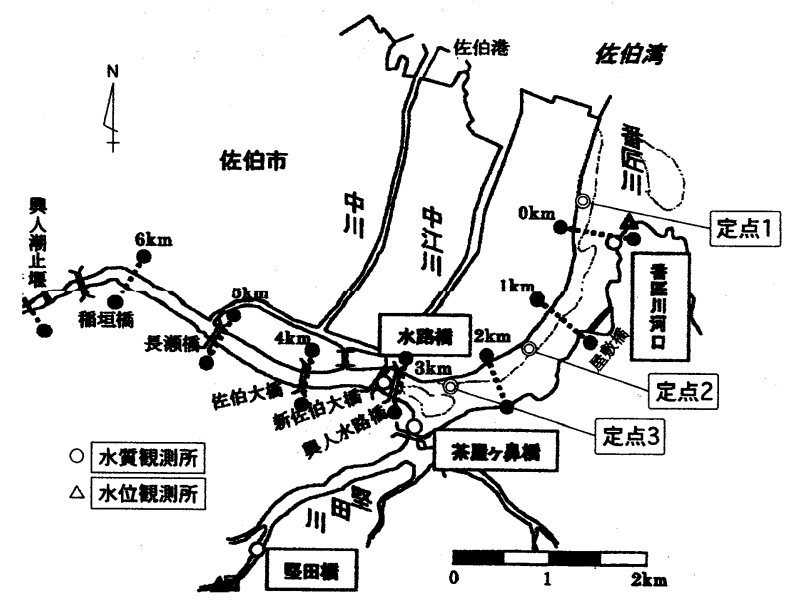

図-1 番匠川河口域の概略図.

\section{（1）番匠川の概略}

調査対象水域である番匠川（図-1）は，大分県南部 の山地に源を発し, 佐伯湾に注ぐ幹線流路延長 $38.1 \mathrm{~km}$, 流域面積 $464 \mathrm{~km}^{2}$ の1級河川であり，全流域面積の $89 \%$ を山 地が占めている. 番匠川本線の河口端より約 $2.5 \mathrm{~km}$ 上流 の地点では堅田川が合流している，河口干潟は，本線 河口端から約 $2.5 \mathrm{~km}$ 上流までの左岸側と河口沖に形成さ れており，その総面積は約 30 haである．感潮区間は約 6. $8 \mathrm{~km}$ であり, 干潮時においても河口端から上流約 $4 \mathrm{~km}$ 付近まで塩水が底層に侵入している. 河口部の佐伯市 では水産業と農業が基幹産業となっており, 河口干潟 ではアサリ，ハマグリおよびクルマエビ等を対象とし た漁業が営まれている3．大分県佐伯漁業共同組合のア サリ漁場は，河口沖および河口端より約 $1.5 \mathrm{~km}$ 上流まで の範囲における右岸側の河道および左岸側の干潟部と なっている゙).

\section{（2）番匠川河口のアサリ漁獲量の推移 ${ }^{3)}$}

番匠川河口におけるアサリ漁業は，1970年代前半ま では流域に立地する工場からの排水污染による水質悪 化のため行われていなかったが，水質污染問題が改善 された1977〜1980年から本格的に実施されるように なった。 そのため, アサリの漁獲量は1984年から急増 し，1989から1993年にかけては約100t/年程度で推移し た.しかし，1994年から急激に低下し，1998年以降は 年漁獲量 $1 \mathrm{t} /$ 年に満たない状態である ${ }^{3)}$. 他の魚貝類を 含む総漁獲量は 1980 年代に入ってから低下が始まり，
その後現在まで低迷している．なお，九州でアサリ漁 の盛んな大分県, 福岡県, 熊本県の農林統計を整理し た結果によると，3県のアサリ資源の減少は1980年代に 既に始まっており，一方，大分県では1985年以降低迷 している. しかし，番匠川河口でのアサリの急减はそ の時期が上述の地域よりも約 10 年程度遅れていること から, 地域固有の問題と判断される. アサリの生育阻 害要因としては, 有機物污染や富栄養化による水質悪 化，底質の粒度変化，捕食性巻貝（ツメタガイ）によ る食害, 生息の場を競合するホトトギスガイや，アオ サなどの大型海藻類の大増殖，重金属等の有害物質の 影響 4)，あるいは上流域の森林の状況の変化等が考えら れるが, いまだ明らかにされていない.

\section{3. 現地観測と実験}

本研究では, 番匠川河口域におけるアサリ漁獲量急 減の原因を究明するための第一歩として, 基礎的な環 境特性を明らかにするため, 本対象水域の特徵であり, 調查の容易な左岸側の河口干潟における生物, 水質, および底質の現況調査を行った. 調査地点と調査期間 ならびに調査項目とその方法は次のとおりとした.

\section{（1）調査地点と調查期間}

調査地点は，番匠川河口から約 $2.5 \mathrm{~km}$ 上流までの区間 の左岸側干潟上の 3 地点（下流加ら順に定点 $1 ， 2 ， 3$, 図-1）とした。調查は2001年8月～2002年7月まで，1力 月に1度の頻度で害施した。また, 調査は干潟が干出す る干潮時の日中に実施した. なお，定点 $1 ， 2 ， 3$ の地盤 高は，それぞれT.P. - - 0. 5m， -0.8m，-0.5mである. ま た, 定点 1 3では塩水遡上の影響を受けるため, 冠水 時の塩分はおよそ34〜36程度となる.

\section{（2）生物調査}

生物調査では, アサリを含む貝類の現存量の把握と, アサリの死滅時期（稚貝あるいは成貝）の特定を行う ため, 各定点における貝類の個体数組成比率およびア サリの生息密度と殼長頻度分布, ならびにアサリの生 息場での競合種であり，干潟上の底質表面に繁茂（堆 積）する海藻類（緑藻アオサおよび紅藻オゴノリ）の 堆積密度を測定した. 貝類の採取は, 塩化ビニル管を 加工して作成した円筒形コアサンプラー (断面積 $100 \mathrm{~cm}^{2}$, 深さ $5 \mathrm{~cm})$ によって行い，採取した底質（100～ $20000 \mathrm{~cm}^{2}$ 相当量）を, $1 \mathrm{~mm}$ メシュ節を用いてふるい分けを行っ て, 篩上の残留物のなかの各種貝類を選別・採取して それぞれの個体数を計数し, 個体数組成比率と密度

(個 $\left./ \mathrm{m}^{2}\right)$ を求めた。特に，アサリについては，実体顕 微鏡（OLMPUS社製, SZH-ILLB) とCCDカメラ（TOSHIBA 社製，IK-1570N）またはデジタルカメラ（NIKON社製， 
COOLPIX990）を用いて撮影し，PC上に取り込み，画像 処理解析ソフト (NIH Image ver. 1.61) を用いて款長 を測定した。海藻類は, それぞれの定点においてコド ラート $(50 \times 50 \mathrm{~cm})$ を用いて底質表面の $0.25 \sim 7.5 \mathrm{~m}^{2}$ を 無作為に抽出して海藻を全量採取し, 海藻種ごとに湿 重量を測定して堆積密度 $\left(\mathrm{g}-\mathrm{wet} / \mathrm{m}^{2}\right)$ を求めた。

\section{（3）水質観測データ}

広範囲に渡る河口域の水質は，国土交通省九州地方 整備局佐伯工事事務所が設置している番匠川河口，茶 屋ヶ鼻橋, および水路橋の3力所の水質観測所の定期観 測データを入手し, 水温, $\mathrm{pH}, \mathrm{D} 0, \mathrm{BOD}, \mathrm{COD}, \mathrm{SS}, \mathrm{T}-\mathrm{N}$, T-Pについて検討した.

\section{（4）底質調查項目}

底質調查として, 底質粒度および中央粒径值, なら びに重金属含有量を測定した，底質は，貝類の採取に 用いた円筒形コアサンプラー（断面積 $100 \mathrm{~cm}^{2}$, 深さ $5 \mathrm{~cm}$ ）を用いて採取し， JSF T 131 「粒度試験方法」に 従って粒度分布および組成比率を測定し，中央粒径值 を求めた。重金属含有量は，粒度調查と同様の方法で

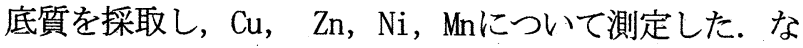
お, 重金属類の分析については, タナべ環境工学 （株）および（株）住化分析センターに依頼した.

\section{4. 調査結果と考察}

\section{（1）生物調查結果}

\section{a）貝類の個体数組成比率とアサリの生息密度}

定点1，2，3における貝類の個体数組成比率の季節変 化を図-2に示す。図中の空欄は調査を実施しなかった ことを表す. 定点1における貝類個体数組成比率は, 調 查月ごとに多少の変動はあるがほぼ年間を通じて安定 しており，採取された貝類全体の50.0〜98.7\%をアサリ が優占した。しかし，定点2でのアサリの占める割合は $12.7 \sim 53.9 \%$ であり, 定点 1 と比較して少なく, 巻貝の ウミニナが多かった. さらに, 定点3では, 貝類全体の 31.6〜84.0\%をウミニナが占めた. この結果より, 調査 地点のなかで最も河口端に近い定点1から最上流部の定 点3に向けてアサリの個体数組成比率は低くなり，一方 でウミニナの組成比率が高くなる傾向があることが明 らかとなった．この原因については，それぞれの定点 における水質および底質等の違いによる影響が考えら れる。これらの影響の有無については, 次節以降に詳 述する.また, アサリの生育阻害要因の一つとして考 えられたアサリの競合種であるホトトギスガイについ ては，本調查ではほとんど採取されず，本調査地点に おけるアサリ減少の原因ではないと考えられる.また， 捕食性巻貝のツメタガイについても同様に本調查にお
いてはほとんど採取されなかった.
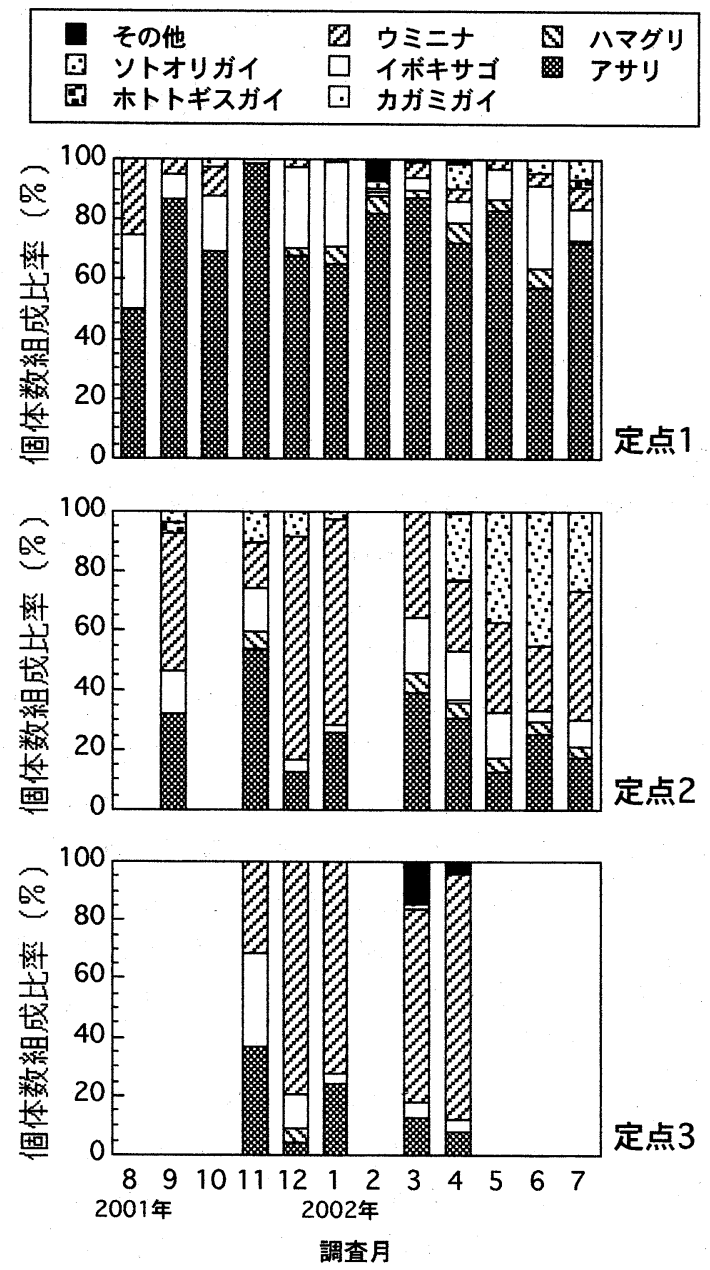

図-2＼cjkstart各定点における貝類個体数組成比率の季節変化.

また，各定点におけるアサリの生息密度（図-3）は，

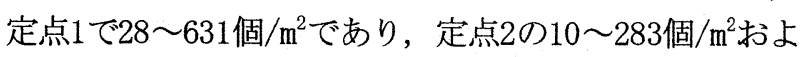
び定点3の $20 \sim 233$ 個 $/ \mathrm{m}^{2}$ と比較して高かった. しかし, 定点1におけるアサリ生息密度の季節変動は大きく, 2001 年 12 月 2002 年 2 月に 100 個 $/ \mathrm{m}^{2}$ 以下となる.アサリ 生息密度は2001年10月を除いて冬季に極めて低くなっ た. 2001 年10月については, 台風 21 号通過直後であっ たことから，台風による増水とそれによる底質の擋乱 がアサリの生息密度に一時的な影響を及ぼしたと考え られる. また, 西日本におけるアサリの産卵時期はお よそ1〜6月あるいは4〜6月であることから ${ }^{4)} ， 2002$ 年3 月からの生息密度の急激な上昇は産卵後の稚貝の新規 加入によるものと思われる. しかし，比較的アサリ生 息密度の高かった 2001 年8月〜11月（10月を除く）およ び2002年3月〜7月においても，その密度は179〜631個 $/ \mathrm{m}^{2}$ であり, 代表的なアサリ漁場である愛知県三河湾や, 山口県大海湾の数千個 $/ \mathrm{m}^{2}$ と比較して $\left.{ }^{5)}, 6\right) ， 1$ オーダー低 い值となっている．アサリの生息密度の変動について は，毎月の調查における均質な採取の困難なこともそ 


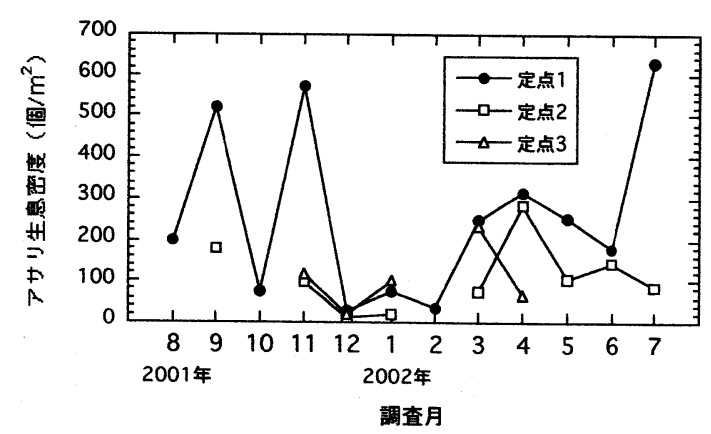

図-3＼cjkstart各定点におけるアサリの生息密度の季節変化.

の要因として考えられる. しかし, 冬季のアサリ密度 の減少（減耗）については, 東京湾盤洲干潟において も報告されており7), 本調查地点においても同様の現象 が起こっている可能性が示唆された.

\section{b）アサリの款長頻度分布}

アサリの成長過程とその死滅時期を把握するため, アサリ密度の最も高い定点1で採取されたアサリのうち, 生存していたもの（生貝）と死亡していたもの（死 貝）とに分別して，それぞれの款長頻度分布を測定し た（図-4）。なお，図-4は，2002年2月～7月の調査分 のみ示している. また, 図中の死貝（穴）とは，捕食 性巻貝のツメタガイによって貝殼に穴を穿たれて死亡 していたアサリを示している.2002年2月の調査におい て採取されたアサリの生貝は, 個体数が少なかったと ともに, 殸長11〜27mmのものに限られていた.また, 死貝もほとんどみられなかった. しかし，同年3月では， 款長1〜2mmおよび2〜3mmの生貝が，それぞれ107個 $/ \mathrm{m}^{2} お$ よび62個/ $\mathrm{m}^{2}$ 採取され，2月下旬から3月初旬の産卵にと もなう稚貝の新規加入がなされたと判断された. しか し, 一方で, 殼長 1 ～ $2 \mathrm{~mm}$ おび2〜 $3 \mathrm{~mm}$ の死貝もそれぞ れ136個 $/ \mathrm{m}^{2}$ および106個 $/ \mathrm{m}^{2}$ となり, 生貝の存在個体数を 上回る個体数が確認された. その後の 4 ～6月では，殸 長1 3mm程度の稚貝の死亡個体数は多くは確認されな かったが，7月の調查においては再び 100 個 $/ \mathrm{m}^{2}$ 以上が確 認された. この結果から, 定点1においてアサリの生息 密度が低くなる原因は, 新規加入直後の稚貝の死亡に よっているのではないかと考えられる. また, ツメタ ガイによって穴を穿たれた死貝の個体数は, その他の 原因による死貝個体数と比較して極めて少なかった. 先述の貝類個体数組成比率においてもツメタガイの採 取個体数は極めて少ないことから, 本調查地点におい ては, ツメタガイがアサリ資源量に大きな影響を与え ることはないといえる.

\section{c）海藻類の堆積密度}

河口干潟に出現する主要な海藻であるアオサとオゴ ノリの堆積密度を図-5に示す.アオサはすべての定点 においてほぼ通年観測されたが，特に，2002年3月〜 5 月の春季において, その密度が最大となった. 定点1, 2, 3におけるアオサの密度の最大值は，それぞれ $90 \mathrm{~g} / \mathrm{m}^{2}$
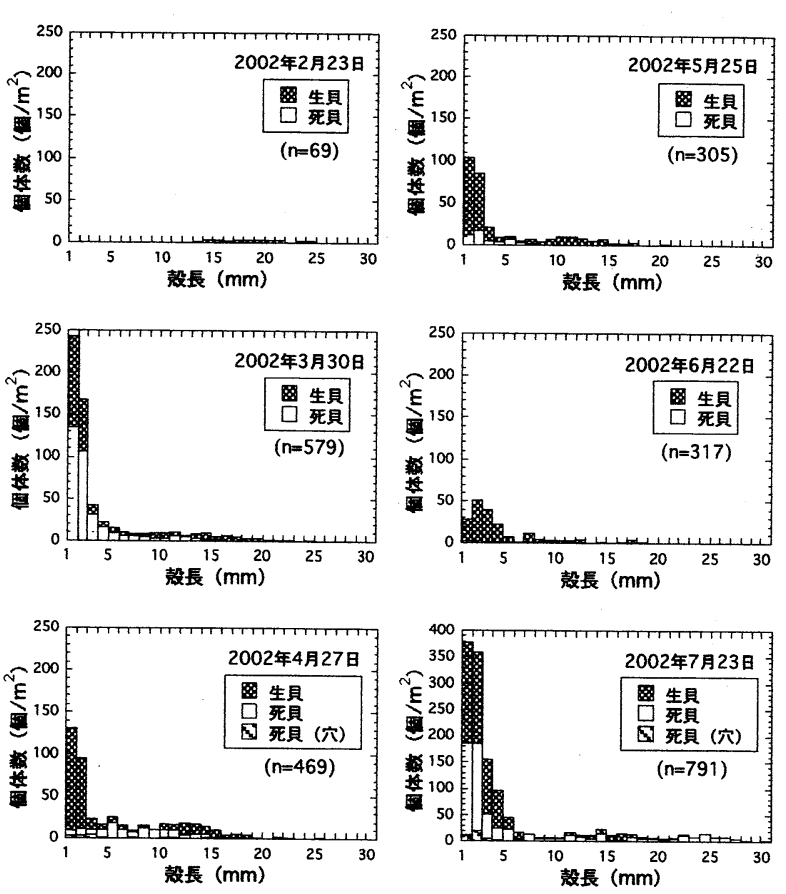

図-4 定点1におけるアサリの款長頻度分布の変化.

（台風21号による出水によって定点 1 付近に局所的にア オサが流入・堆積した 2001 年10月を除く），3486 $/ \mathrm{m}^{2}$, $5684 \mathrm{~g} / \mathrm{m}^{2}$ であり, 定点 2 と 3 で極めて高い值を示した.こ れらの值は，「グリーンタイド」として問題となって いる高知県浦ノ内湾等での堆積密度に匹敵する値であ $り^{8)}$, 定点2および3の左岸堤防付近では, 堆積したアオ サが腐敗することによって生じたと思われる底質の嫌 気化が年間を通じて観察された．同定点付近には，女 島书門および女島樋管が設置されており，干潮時には 農業排水が流れ込んでいる. アオサの増殖はこれらの 排水からの栄養塩の供給によるものと考えられた。一 方, オゴノリは, 冬季〜春季である 2002 年 1 月〜 $~ 5$ 月に のみ出現し, 定点 2 では最大 $4452 \mathrm{~g} / \mathrm{m}^{2}$ が観測された.ア オサおよびオゴノリの増殖期である3～5月は，アサリ の産卵および稚貝の新規加入時期と重なるため, これ ら海藻の大増殖がアサリの稚貝の生育に影響を及ぼし ている可能性が考えられる.

\section{（2）水質観測結果}

2001 年8月～2002年7月における番匠川河口域の水質 観測所における観測結果を図-6に示す. 3力所の水質観 測所における水質は，互いに際だった差異は認められ ず，同様の傾向を示した. 3力所の水質観測地点におい て, 調査期間を通じて, 水温は9. $1 \sim 31.0^{\circ} \mathrm{C}, \mathrm{pH}$ は 6.9 〜8.2の範囲を変動し， D0は6. $4 \mathrm{mg} / 1$ 以上，BODおよび CODは1.3mg/1および3. 4mg/1以下, SSは4mg/1以下とな り，良好な水質を示した。しかし，T-Nは調查期間を通 じて0.59 0.89mg/1, T-Pは, 2001年8月の茶屋ヶ橋水 質観測所において0.093mg/1の高い值を示し，それ以外 の月のすべての観測所においても0. 012〜0. 035mg/1と 

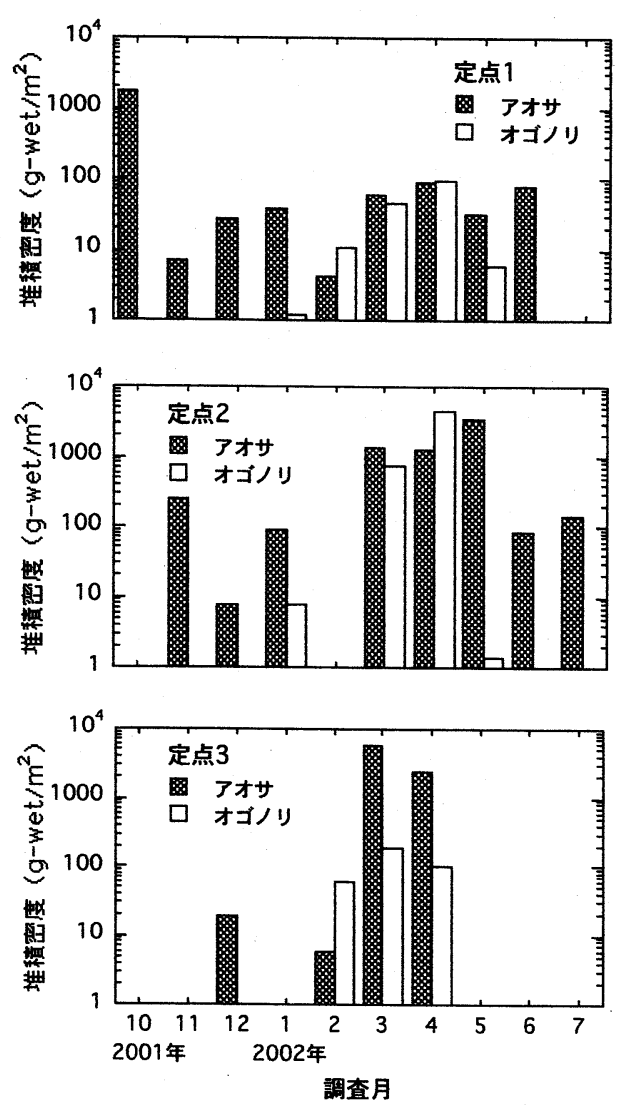

図-5 各定点における海藻類の堆積密度の季節変化.

なり，富栄養化傾向にあることが認められた．これら の栄養塩類の増加がアオサの増殖を助長すると考えら れる. 河口域全体における栄養塩濃度の上昇は樋門・ 樋管からの負荷だけでなく, 番匠川上流や堅田川から の負荷も考えられることから，これらの流入負荷量と その水質への影響については今後検討寸る必要がある.

\section{（3）底質調査結果}

\section{a）底質粒度組成比率と中央粒径值}

各定点における底質の粒度組成比率を図-7に示す。 最下流部の定点1では年間を通じて粒径106〜250 $\mu \mathrm{m}$ の 細砂および粒径250〜 $425 \mu \mathrm{m}$ の中砂の合計值が底質全体 の66. 6 85. 2\%を占め, 粒径75 $\mu \mathrm{m}$ 以下の粘土・シルト 成分は $0.65 \sim 10.3 \%$ ，粒径 $850 \mu \mathrm{m}$ 以上の碟分は0.1〜 0. 8\% と少なかった（中央粒径值180〜 $333 \mu \mathrm{m}$ ) 。定点 2 では細砂および中砂が底質全体の47.5〜 79.2\%となり， 定点 1 と比較して少なかった。一方で，定点2では粘 土・シルト成分が底質全体の3.0〜22.7\%，磁分が1.7〜 $8.7 \%$ となり, 定点 1 と比較して多かった（中央粒径值 $240 \sim 357 \mu \mathrm{m})$ 。これらに対して，定点3では礫分以上 の粒径のものが底質全体の $66.2 \sim 86.9 \%$ 占め, 細砂お よび中砂を含む砂分は極めて少なかった（中央粒径値 2291 5410 $\mu \mathrm{m}$ ）。これらの結果から，最下流部の定点

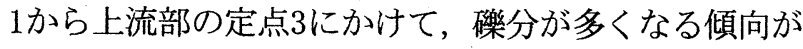
明らかとなった. アサリの生育には細砂および中砂が
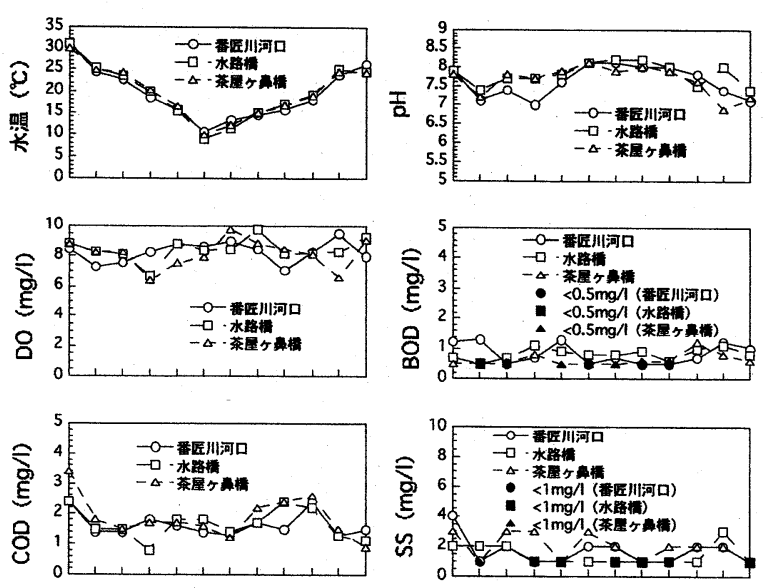

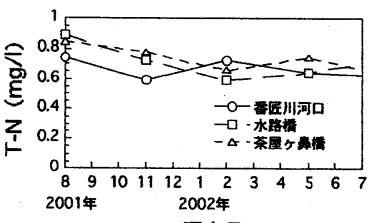

調査月

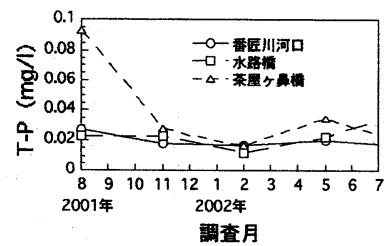

図-6 水質観測結果（2002年1月～7月は速報值）。

適しており，粘土・シルト成分や礫分が多い環境には 適していない5)。先述の貝類個体数組成比率における定 点1から3に向けてのアサリの組成比率の低下とウミニ ナの割合の上昇は，底質粒度組成比率における䃇分の 組成比率の上昇と一致することから，各定点における 貝類個体数組成比率の差異は底質粒度による影響が大 きいといえる.

\section{b) 重金属含有量}

各定点における底質の重金属含有量は，2001年7月～ 2002年5月までの分析結果によると, Cuが定点1で3.9〜 $7.0 \mathrm{mg} / \mathrm{kg}$, 定点 2 で $6.3 \sim 9.0 \mathrm{mg} / \mathrm{kg}$, 定点 3 で $4.2 \sim$ $7.5 \mathrm{mg} / \mathrm{kg}, \quad \mathrm{Zn}$ が定点 1 で $36 \sim 50 \mathrm{mg} / \mathrm{kg}$, 定点 2 で $33 \sim$ $50 \mathrm{mg} / \mathrm{kg}$, 定点 3 で $21 \sim 39 \mathrm{mg} / \mathrm{kg}, \mathrm{Ni}$ が定点 1 で $7.7 \sim$ $15 \mathrm{mg} / \mathrm{kg}$, 定点 2 で $14 \sim 20 \mathrm{mg} / \mathrm{kg}$, 定点 3 で6. 7 $16 \mathrm{mg} / \mathrm{kg}$, Mnが定点1で150〜340mg/kg, 定点2で190〜 290 mg $/ \mathrm{kg}$, 定点3で140 290mg/kgであった. 山口県瀬戸内海沿岸 におけるアサリ漁場の底質の重金属含有量の平均值は, Cuが5. 9ppm，Znが36ppm，Niが6. 8ppm，Mnが124ppm等， が報告されており ${ }^{9)}$, 定点1,2,3における重金属含有量 の最大值はこれらの報告值に比較して約1.5～3倍程度 高い值であった．重金属類がアサリの生育に及ぼす影 響濃度については，まだ充分な知見が得られていない ため，今後バイオアッセイによって，底質重金属濃度 とアサリの生育との関係を明らかにする必要がある.

\section{5. まとめ}

番匠川河口干潟におけるアサリ資源急減の原因究明 を目的として，2001年8月〜2002年7月に現地観測を行 

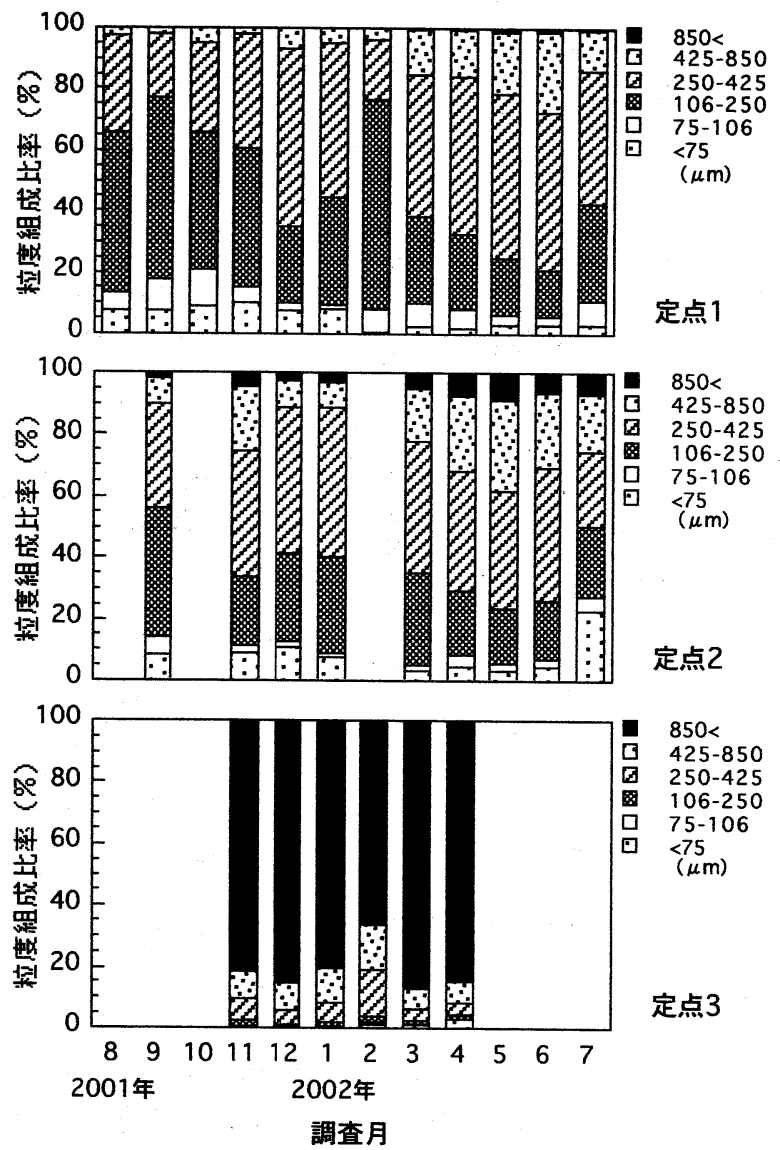

図-7 各定点における底質の粒度組成比率の季節変化.

った結果，以下の知見を得た

1）採取された貝類のなかで, アサリの個体数組成比 率は, 河口端の干潟（定点1）で最も高く，そひ 值は50.0〜98.7\%であった。 しかし，その密度は 低く，最大で631個/的であった.

2）定点1では12月～1月におけるアサリ密度の減少と, 3月および7月における稚貝の死亡が認められた.

3）河口端より $1.5 \mathrm{~km}$ および2. $5 \mathrm{~km}$ 上流の干潟（定点 2 , 3）ではアサリの密度が低かった，底質中の䃋分 の割合が多いことが主要な原因と考えられる.

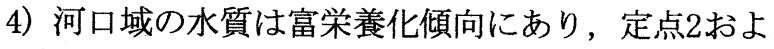
び3では，3〜5月において，富栄養化にともなう 大型海藻であるアオサの大増殖が観測された。

5）すべての定点において，捕食性巻貝であるツメタ ガイあるいはアサリの競合種であるホトトギスガ イの個体数は少なく，アサリ資源量に対する影響 はないと考えられた。

6) すべての定点における底質の重金属含有量（Cu, $\mathrm{Zn}, \mathrm{Ni}, \mathrm{Mn}$ ）は，代表的なアサリ漁場と比較して やや高い傾向を示した.

以上の結果から, 番匠川河口干潟における貝類の個 体数組成比率は底質粒度に影響されるものの，アサリ 資源量の低下の原因は冬季の減耗と稚貝の新規加入直 後の死亡によるものが大きいと考えられる．また，富
栄養化にともなう大型海藻類の大増殖や底質の重金属 含有量の増加はアサリの生息密度の低下に影響を及ぼ す可能性がある. 一方で, ツメタガイによる捕食やホ トトギスガイによる生息場での競合については，これ らの生息密度が低いため，アサリ資源量に影響を及ぼ さないことが分かった，今後は，本研究では未調査で あった右岸側河道部および海域の調查を実施するとと もに, 樋門・樋管等からの栄養塩負荷量と, 海藻の腐 敗に伴う底質の嫌気化や重金属類による貝類への影響, ならびにこれらの対策としての河川管理方法について 検討する予定である.

謝辞 : 本研究は, 土木学会水理委員会河川懇談会の共 同研究計画「汽水域の環境特性に関する研究（番匠 川）」の一環である.アサリ資源の生物学的検討につ いては熊本県立大学の堤裕昭教授, 現地の漁業等につ いては西日本技術研究所の工藤勝宏氏にご教示を頂い た. 佐伯工事事務所鶴崎秀樹氏，小犬丸智明氏，草野 裕一氏には研究全般にわたってご尽力頂いた。記して ここに感謝申し上げる.

\section{参考文献}

1) 清野聡子, 宇多高明, 三船修司 : 過去の地形条件における 希少生物カブトガニの粰化幼生の分散課程の復元と生息地 保全，水工学論文集，第46巻，pp.1181-1186， 2002.

2) 宇野宏司, 中野晋 : 吉野川河口に扔ける塩分環境とシオマ ネキ幼生分布状況, 水工学論文集, 第46巻, pp.1175-1180, 2002.

3) 清野聡子, 小松利光, 安達貴浩, 井上徹教, 高見徹, 中茂 義晶, 別府五男, 郡山貞次 : 水産生物資源の変動に関する 複合的要因の解明過程における課題一大分県番匠川河口干潟 のアサリを例として-, 環境システム研究論文集, 第30巻, 2002.

4)（社) 全国沿岸漁業振興開発協会: 沿岸漁場整備開発事業 増 殖場造成計画指針 ヒラメ・アサリ編（平成8年度版）， pp.123-164, 1996.

5) 西沢正, 日向野純也, 田口浩一, 伊藤覚 : 三河湾における アサリ稚貝の分布量と底質および流れとの関係, 水産工学, 第32巻, pp.137-143, 1995.

6) 井上泰 : 山口・大海湾におけるアサリの生態と環境につい て, 水産土木, 第16巻, pp.29-35, 1980.

7) 柿野純，古畑和哉，長谷川健一：東京湾盤洲干潟における 冬季のアサリのへい死要因について, 水産工学, 第32巻, pp.23-32, 1995.

8) 大野正夫 : アオサと大繁殖, アオサの利用と環境修復（能 登谷正浩編)，pp.1-15, 成山堂書店, 東京, 1999.

9) 熊谷洋, 佐伯清子 : 底質とアサリの重金属含量について, 日本水産学会誌, 第48巻, pp.837-841, 1982.

(2002. 9. 30受付) 